\title{
HEALTH LITERACY AND ORAL HEALTH: THE ROLE OF SCHOOLTEACHERS AS HEALTH PROMOTERS
}

\section{WIEDZA 0 ZDROWIU ORAZ ZDROWIE JAMY USTNEJ - ROLA NAUCZYCIELI SZKOLNYCH JAKO PROMOTORÓW ZDROWIA}

\author{
Luís Soares Luís ${ }^{1,2(A)}$, Victor Assunção ${ }^{2,3(A)}$, Henrique Luís ${ }^{2,3(A)}$ \\ ${ }^{1}$ Polytechnic Institute of Leiria, Portugal \\ ${ }^{2}$ Center for Innovative Care and Health Technology (ciTechCare), Polytechnic of Leiria, Portugal \\ ${ }^{3}$ Faculty of Dental Medicine, University of Lisbon, Portugal
}

Authors' contribution

Wkład autorów:

A. Study design/planning

zaplanowanie badań

B. Data collection/entry

zebranie danych

C. Data analysis/statistics

dane - analiza i statystyki

D. Data interpretation

interpretacja danych

E. Preparation of manuscript

przygotowanie artykułu

F. Literature analysis/search wyszukiwanie i analiza literatury

G. Funds collection

zebranie funduszy

\section{Dear Editor,}

The recognition of literacy's relevance led the UN to declare in 2002 the "United Nations Decade for Literacy". The UN Secretary-General's message, on September $8^{\text {th }}, 2012$, at the International Literacy Day celebrations, refers that "[l]iteracy provides tools for men and women to better understand the world and shape it to meet their aspirations. It is a source of individual dignity and a motor for the healthy development of society", adding that "a literate world is a more peaceful world, and a more harmonious and healthier world" [1].

Health literacy is likewise relevant since it is a key competence in the development of public health. It can be defined as an individual's ability to identify, understand, interpret, create, communicate, and use health information in a way that promotes their health. Extending this concept to oral health, its development is fundamental. The World Dental Federation (FDI) published a report saying that the increasing recognition of healthy behaviors and health literacy is essential for the prevention of oral diseases and for the promotion of oral health and should be part of strategies for improving oral health [2].

Oral health is a determinant factor for quality of life, crucial for the well-being and an essential part of general health.

Dental diseases are the most prevalent diseases among schoolchildren. Health education programs should begin in childhood and evolve based on acquired knowledge. Schools are a starting point for promoting health and oral health in families and community. Teachers can be empowering elements in the creation of health and oral health promotion messages and spread information to their families, student's families, and community, thus contributing to the promotion of knowledge and health in an area that is a serious problem in child and adolescent population.

Acquiring an adequate level of health literacy can be hampered by the lack of continuity in health education programs for different age groups. Teachers, trained as health promoters, can influence the effectiveness of health and health literacy knowledge transmission, and constitute catalysts of the community where they are inserted, leading the population to a successful health maintenance.

It is our intention to develop educational and training programs to schoolteachers, for them to become health promoting agents, and to develop pedagogic material

Keywords: health literacy, oral health, health promotion, schoolteachers

Słowa kluczowe: wiedza o zdrowiu, zdrowie jamy ustnej, promocja zdrowia, nauczyciele szkolni

Tables: 0 
that guarantee the continuity of the activities throughout time, assuring a multidisciplinary approach, ranging from nutrition, nursing, oral health, public health, and multimedia knowledge, based on a strong scientific and technical input. The common goal is to promote quality of life through the development of activities on health, nutritional and oral health issues.

Empowering teachers, by educational interventions and technical skills acquisition, results in the empowerment of the community, in which they have a predominant role, resulting in higher levels of health literacy, basic nutrition knowledge as well as of general and oral health, essential to promote health and consequently to promote quality of life. Their involvement is paramount for the development of health promotion activities, by reaching a group of individuals from early childhood to adulthood.

\section{References:}

1. United Nations. Secretary-General's message on International Literacy Day 2012 [Internet]. New York: United Nations; 2012 Sep 8 [cited 2021 Jul 26]. Available from: https://www.un.org/sg/en/content/sg/ statement/2012-09-08/secretary-generals-message-international-literacy-day

2. FDI. Oral health worldwide a report by FDI World Dental Federation. Geneve: FDI World Dental Federation; 2014. 